\title{
Bioactivity Formulation of Leaf Extract of Kalanchoe pinnata And Seed of Azadirachta indica Against Spodoptera litura
}

\author{
Hedi Paramita ${ }^{1}$, Lindung Tri Puspasari ${ }^{2}$, Yusup Hidayat ${ }^{2}$, Rika Meliansyah $^{2}$, Danar Dono $^{2 *}$, \\ Rani Maharani ${ }^{3}$, Unang Supratman ${ }^{3}$ \\ ${ }^{1}$ Graduate of Department of Plant Pests and Diseases, Agriculture Faculty, Universitas Padjadjaran, Jatinangor, West Java, \\ Indonesia, 45363 \\ ${ }^{2}$ Department of Plant Pests and Diseases, Agriculture Faculty, Universitas Padjadjaran, Jatinangor, West Java, Indonesia, \\ 45363 \\ ${ }^{3}$ Departement of Chemistry, Faculty of Mathematic and Natural Sciences, Universitas Padjadjaran, Jatinangor, \\ West Java, Indonesia, 45363 \\ *Corresponding Author: danar.dono@unpad.ac.id
}

\begin{abstract}
The awareness of importance of pest control technology environmentally friendly encourage to explore bioactive compound especially from plant. Some of plant bioactive compound had formulated to increase the effectiveness and easy of the use. The aim of this research is to know the most effective concentration of liquid formulation of Kalanchoe pinnata leaf extract $50 \mathrm{EC}$ and Azadirachta indica seed extract $50 \mathrm{EC}$ against $S$. litura. The experiment was conducted at the Laboratory of Pesticides and Enviromental Toxicology, Department of Plant Pests and Diseases, Faculty of Agriculture, Universitas Padjadjaran. The concentration tested for each formulation were $1 \%, 2 \%, 3 \%, 4 \%$, and control. The experiment arranged in completely randomized design (CRD) and replicated three times. The results showed that the formulation of $A$. indica seed extract $50 \mathrm{EC}$ at concentration of $2 \%, 3 \%$, and $4 \%$ effective against S. Litura larvae with mortality of $76.7 \%, 86.7$, and $93.3 \%$. This formulation also causing a decrease in feeding activity, weight, and lenghten the development time of $S$. litura larvae. Unlike the case with liquid formulations of $K$. pinnata $50 \mathrm{EC}$ extract which was less toxic and did not significant differences in food consumption, weight and development time of larvae compared control treatment.
\end{abstract}

Keywords: Toxicity, mortality, growth dearragement, botanical insecticide.

\section{ABSTRAK}

Bioaktivitas Formula Ekstrak Daun Kalanchoe pinnata dan Biji Azadirachta indica Terhadap Spodoptera litura

Kesadaran akan pentingnya teknologi pengendalian hama yang ramah lingkungan mendorong pencarian senyawa bioaktif alami khususnya yang berasal dari tumbuhan dan untuk meningkatkan keefektifan dan kemudahan penggunaannya senyawa bioaktif tumbuhan tersebut telah diformulasikan. Penelitian bertujuan untuk mengetahui konsentrasi yang efektif dari formulasi cair ekstrak daun cocor bebek (K. pinnata) dan biji mimba (A. indica) terhadap S. litura. Penelitian dilaksanakan di Laboratorium Pestisida dan Toksikologi Lingkungan, Departemen Hama dan Penyakit Tumbuhan, Fakultas Pertanian, Universitas Padjadjaran yang dimulai dari bulan April sampai dengan Juni 2015. Perlakuan yang diuji yaitu formulasi cair ekstrak daun $K$. pinnata 50 EC konsentrasi 1\%, 2\%, 3\%, 4\%, dan formulasi cair ekstrak biji A. indica 50 EC konsentrasi 1\%, $2 \%, 3 \%, 4 \%$ serta kontrol, masing-masing perlakuan diulang sebanyak tiga kali. Percobaan disusun dalam rancangan acak lengkap (RAL). Hasil penelitian menunjukkan bahwa konsentrasi efektif perlakuan formula ekstrak biji A. indica $50 \mathrm{EC}$ yaitu konsentrasi $2 \%$ dengan mortalitas sebesar 76,67\%. Perlakuan formulasi cair ekstrak biji A. indica 50 EC juga mengakibatkan penurunan aktivitas makan, bobot larva, dan memperpanjang lama perkembangan S. litura. Berbeda halnya dengan formulasi cair ekstrak $K$. pinnata $50 \mathrm{EC}$ yang kurang toksik dan tidak menunjukkan perbedaan yang nyata pada konsumsi pakan, bobot dan lama perkembangan larva dibanding kontrol.

Kata Kunci : Toksisitas, mortalitas, gangguan perkembangan, insektisida botani.

\section{PENDAHULUAN}

Hingga saat ini umumnya pengendalian hama masih mengandalkan penggunaan pestisida sintetik. Penggunaan pestisida sintetik dinilai memiliki keefektifan yang tinggi. Akan tetapi penggunaan secara intensif akan berdampak buruk terhadap lingkungan, organisme non-target dan kesehatan. Residu bahan aktifnya juga sulit terurai (Metcalf dan Luckmann, 1982). Penggunaan pestisida sintetik secara terus menerus dapat menimbulkan resistensi dan resurgensi hama. Efek dari pestisida sintetik yang berbahaya terhadap lingkungan tersebut mendorong para peneliti untuk menemukan senyawa insektisida nabati baru yang lebih ramah lingkungan. Tuntutan terhadap keselamatan lingkungan membuat pestisida nabati lebih banyak digunakan dengan alasan kegunaan lebih selektif serta relatif tidak membahayakan bagi organisme non-target.

Tanaman Azadiractha indica A. Juss (Meliaceae) merupakan salah satu tanaman yang sering digunakan sebagai pestisida nabati karena mengandung zat toksik anti serangga. Senyawa aktif azadirachtin pada tanaman mimba dapat menghambat pertumbuhan serangga, mengganggu aktifitas makan, mengurangi produksi dan penetasan telur, meningkatkan mortalitas, mengaktifkan infertilitas imago mengurangi fekunditas dan sebagai repellen hama (penolak) (Gruber dan Karganilla, 1989). 
Salah satu sumber bahan alami lainnya yang memiliki senyawa insektisida adalah tanaman dari genus Kalanchoe. Tanaman ini sebelumnya sudah banyak digunakan oleh masyarakat Indonesia sebagai obat infeksi, rematik, batuk, demam dan radang (Hutapea, 1994). Kalanchoe kaya akan kandungan alkaloid, triterpena, glikosida, flavonoid, steroid dan lipida, sedangkan pada daunnya terkandung senyawa kimia yang disebut bufadienolida (Pattewar, 2012). Menurut penelitian Supratman et al. (2000) pada ekstrak methanol Kalanchoe pinnata terdapat dua senyawa insektisida yaitu Bryrophyllin $A$ dan Bryrophyllin $C$ yang termasuk kedalam golongan bufadienolida. Senyawa Bryrophyllin $A$ dan Bryrophyllin $C$ menunjukkan aktivitas insektisida yang kuat pada instar tiga larva ulat sutera (Bombyx mori) dengan $\mathrm{LD}_{50}$ masing-masing 3 dan $5 \mu \mathrm{g} / \mathrm{g}$ diet. Menurut penelitian Mayanti dkk. (2011), ekstrak cocor bebek dari spesies Kalanchoe daigremontiana yang memiliki genus yang sama dengan $K$. pinnata juga memiliki sifat insektisidal akibat terdapatnya senyawa daigremontianin. Senyawa tersebut menunjukkan aktivitas insektisida yang kuat terhadap instar ke tiga $B$. mori dengan $\mathrm{LD}_{50} 0,9 \mu \mathrm{g} / \mathrm{g}$ diet.

Penelitian ini, bertujuan untuk mengetahui pengaruh kedua formulasi cair pestisida nabati tersebut (A. indica dan $K$. Pinnata) terhadap Spodoptera litura.

\section{BAHAN DAN METODE}

\section{Perbanyakan dan Pemeliharaan Serangga Uji}

Larva $S$. litura yang digunakan berasal dari lahan sayuran kubis di Balai Penelitian Tanaman Sayuran (BALITSA) Lembang, Kabupaten Bandung. Larva serangga uji yang diujikan merupakan serangga generasi kedua yang didapatkan dari dari lapangan, kemudian diperbanyak di ruang perbanyakan serangga, Departemen Hama Penyakit Tumbuhan, Fakultas Pertanian, Universitas Padjadjaran.

Larva diperbanyak pada wadah berbentuk tabung (diameter $21,5 \mathrm{~cm}$ dan tinggi $22 \mathrm{~cm}$ ) dengan penutup terbuat dari kain kasa untuk sirkulasi udara. Larva diberi pakan daun talas berbatang hijau (Xanthosoma sagittifolium H.W. Schott \& Endl.). Ketika larva sudah menunjukkan fase pra-pupa, dipindahkan kedalam wadah lain yang pada bagian bawah wadah biakan diberi tanah untuk perkembangan pupa lalu ditempatkan dalam kurungan berukuran 40 x 40 x $40 \mathrm{~cm}$. Setelah pupa berkembang menjadi imogo, untuk peletakan telur dalam kurungan tersebut ditempatkan daun talas yang pangkal tangkai daunnya dicelupkan ke dalam wadah berisi air agar daun tetap segar. Imago $S$. litura diberi pakan madu yang diserapkan pada kapas dan digantung pada bagian atas kurungan. Telur S. litura yang diletakkan pada daun talas tersebut diambil setiap hari kemudian ditempatkan dalam wadah plastik berukuran 10 x 8 x $5 \mathrm{~cm}$. Larva instar 1 berumur 1 hari yang menetas dari telur generasi ke-2 digunakan untuk pengujian.

\section{Pelaksanaan Pengujian}

Perlakuan yang diuji yaitu formulasi cair ekstrak $K$. pinnata $50 \mathrm{EC}$ dan formulasi cair ekstrak A. indica yang diperoleh dari Laboratorium Pestisida dan Toksikologi Lingkungan dan merupakan hasil riset pengembangan formula insektisida dengan peneliti Prof. Unang Supratman dan Dr. Danar Dono. Masing-masing formula diuji pada konsentrasi $1 \%, 2$ $\%, 3 \%$ dan $4 \%$.

Setiap konsentrasi dibuat dengan pengencer akuades. Sebagai contoh konsentrasi $1 \%$ dibuat dengan mengambil $0,25 \mathrm{ml}$ formula $K$. pinnata $50 \mathrm{EC}$ atau $A$. indica 50 EC menggunakan pipet lalu dimasukkan ke dalam labu takar $25 \mathrm{ml}$. Ke dalam labu tersebut kemudian ditambahkan akuades sedikit demi sedikit sambil digoyangkan hingga volume akhir mencapai $25 \mathrm{ml}$. Labu takar ditutup lalu larutan dikocok hingga homogen. Perlakuan konsentrasi lainnya dibuat dengan cara serupa. Pakan larva perlakuan berupa daun talas yang dipotong dengan ukuran $4 \mathrm{x} 4 \mathrm{~cm}$. Daun tersebut kemudian dicelupkan ke dalam larutan formula insektisida dengan konsentrasi tertentu dalam beaker glass. Pencelupan menggunakan pinset steril dan dilakukan secara berurutan mulai dari perlakuan kontrol hingga konsentrasi tertinggi. Pakan yang telah dicelupkan kemudian dikeringanginkan dengan meletakkan daun pakan diatas kertas serap hingga benar-benar kering dari larutan formula insektisida. Kemudian daun pakan tersebut dimasukkan ke dalam cawan petri berdiameter $9 \mathrm{~cm}$ yang telah diberi alas kertas serap. Ke dalam setiap cawan petri dimasukkan 10 ekor larva S. litura instar I menggunakan kuas halus nomor 3. Pemberian daun pakan berperlakuan dilakukan selama 48 jam. Pada hari selanjutnya daun pakan berperlakuan diganti dengan daun pakan tidak berperlakuan. Pengamatan dilakukan setiap hari dengan waktu yang sama hingga larva yang bertahan hidup mencapai instar ke-4. Pergantian pakan dilakukan setiap 2 hari sekali.

Peubah yang diamati ialah mortalitas larva instar I hingga instar IV, waktu perkembangan larva, bobot pakan dikonsumsi larva, bobot larva instar IV serta keberhasilan perkembangan larva hingga mencapai fase imago. Percobaan disusun dalam rancangan acak lengkap dengan tiga kali ulangan. Data dianalisis dengan sidik ragam dan dilanjutkan dengan uji jarak berganda Duncan (Steel \& Torrie, 1993).

Pengamatan mortalitas dan waktu perkembangan larva dilakukan setiap hari setelah perlakuan. Pengamatan waktu perkembangan larva dimulai dari 1 Hari Setelah Perlakuan (HSP) yaitu pada saat larva pada instar I hingga larva instar IV, pupa dan hingga menjadi imago.

Pengamatan konsumsi pakan dilakukan pada saat 48 jam setelah pemberian daun perlakuan. Daun ditimbang sebelum diberikan kepada larva dan ditimbang kembali setelah dua hari setelahnya. Daun setelah perlakuan yang telah ditimbang kemudian di 
keringkan dengan oven pada suhu $95^{\circ} \mathrm{C}$ selama 24 jam untuk mendapat bobot kering.

Pengamatan bobot larva dilakukan pada larva instar IV yang bertahan hidup. Larva instar IV dikeringkan menggunakan oven dengan suhu $95^{\circ} \mathrm{C}$ selama 24 jam untuk mendapat bobot keringnya.

\section{HASIL DAN PEMBAHASAN}

Pengaruh Formulasi Cair Ekstrak Daun $K$. pinnata 50 EC dan Biji A. indica 50 EC terhadap Mortalitas Larva $S$. litura

Perlakuan formulasi cair ekstrak biji A. indica 50 EC memiliki tingkat efektivitas yang lebih tinggi dibanding dengan formulasi cair ekstrak daun $K$. pinnata 50 EC (Tabel 1). Perlakuan dengan tingkat kematian tertinggi berada pada perlakuan formulasi cair ekstrak biji $A$. indica 50 EC pada konsentrasi tertinggi yaitu $4 \%$ dengan persentase kematian sebesar 93,33\%, sedangkan kematian terendah yaitu berada pada formulasi cair ekstrak daun $K$. pinnata 50 EC pada konsentrasi terendah yaitu $1 \%$ dengan persentase kematian yang terjadi sebesar 16,67\%.

Perkembangan tingkat mortalitas pada perlakuan $A$. indica lebih tinggi dibandingkan perlakuan $K$. pinnata yang terjadi pada hari ke-2 hingga hari ke-6 setelah perlakuan (HSP), sedangkan untuk perlakuan $K$. pinnata perkembangan tingkat mortalitas lebih datar serta mulai teramati pada 2 sampai 8 HSP (Gambar 1 dan 2). Hal ini mengindikasikan bahwa formula ekstrak $A$. indica 50 EC memiliki sifat yang lebih toksik dibanding formula ekstrak K. Pinnata 50 EC. Kematian yang tinggi pada perlakuan $A$. indica salah satunya disebabkan karena senyawa azadirachtin pada biji mimba yang dapat menyebabkan gangguan pelepasan neurohormon dari corpora cardiaca yang selanjutnya menyebabkan terjadinya gangguan terhadap pengaturan hormon perkembangan (ecdysone hormone dan juvenile hormone) (Rembold 1988). Namun, penelitian yang dilakukan oleh Supratman et al (2000) menunjukkan bahwa ekstrak yang terkandung dalam $K$. pinnata yaitu senyawa byrophyllin A dan byrophyllin $\mathrm{C}$ menunjukkan sifat insektisida terhadap larva ulat sutera (Bombyx morii) dengan $\mathrm{LD}_{50} 3$ dan $5 \mu \mathrm{g} / \mathrm{g}$ diet dengan cara perlakuan secara oral. Penelitian yang telah dilakukan oleh Melanie dkk, (2004) ekstrak cocor bebek ( $K$. daigremontiana) memiliki efek antifeedant, tidak bersifat toksik terhadap larva instar IV awal Epilachna vigintioctopunctata. Selain itu, juga menurunkan kemampuan lolos hidup $E$. vigintioctopunctata yang merupakan bangsa Coleoptera (Melanie dkk, 2006).

\section{Pengaruh Formulasi Cair Ekstrak K. pinnata 50 EC dan $A$. indica 50 EC terhadap Aktivitas Makan Larva $S$. litura}

Rata-rata bobot pakan yang dikonsumsi pada kedua ekstrak yang diujikan menunjukkan hasil yang berbeda nyata, akan tetapi perlakuan konsentrasi pada ekstrak yang sama tidak menunjukkan hasil yang berbeda nyata (Tabel 2). Rata-rata bobot pakan perlakuan formulasi cair ekstrak daun $K$. pinnata 50 EC menunjukkan hasil yang tidak berbeda nyata dengan kontrol. Pada kedua perlakuan formula, terdapat kecenderungan menunjukkan penurunan aktivitas makan larva $S$. litura seiring dengan bertambahnya konsentrasi. Penurunan aktivitas makan larva $S$. litura pada perlakuan $A$. indica, disebabkan karena senyawa-senyawa bioaktif yang terkandung pada mimba yaitu azadirachtin, Salanin, dan Meliantriol memiliki aktivitas penghambat makan larva. Efek primer dari Azadiracthin terhadap serangga berupa antifeedant dengan menghasilkan stimulan penolak makan spesifik terhadap reseptor kimia pada bagian alat mulut yang bekerja bersamasama dengan reseptor kimia lainnya yang mengganggu persepsi rangsangan untuk makan (Mordue et al. 1998). Salanin yang mempunyai daya kerja sebagai penghambat makan serangga (antifeedant), dan Meliantriol memiliki daya kerja sebagai penolak serangga (repellent) (Sudarmadji 1993; Wowiling, 2010).

Tabel 1. Mortalitas larva S. litura instar I himgga IV pada 13 HSP perlakuan formulasi cair ekstrak daun $K$. pinnata 50 ECdan A. indica 50 EC pada berbagai taraf konsentrasi

\begin{tabular}{ccc}
\hline \multirow{2}{*}{ Perlakuan } & \multicolumn{2}{c}{$\begin{array}{c}\text { Mortalitas (\%) } \\
(\overline{\boldsymbol{x}} \pm \mathbf{S B})\end{array}$} \\
\hline \multirow{2}{*}{ Kp 50 EC } & Kontrol & $6,67 \pm 4,71 \mathrm{a}$ \\
& Kp 1\% & $16,67 \pm 4,71 \mathrm{ab}$ \\
& Kp 2\% & $26,67 \pm 17,00 \mathrm{bc}$ \\
Ki 50 EC & Kp 3\% $4 \%$ & $33,33 \pm 4,71 \mathrm{bc}$ \\
& Ki 1\% & $46,67 \pm 12,47 \mathrm{~cd}$ \\
& Ai 2\% & $56,67 \pm 9,43 \mathrm{de}$ \\
& Ai 3\% & $76,67 \pm 17,00 \mathrm{ef}$ \\
& Ai 4\% & $86,67 \pm 4,71 \mathrm{f}$ \\
& Ki & $93,33 \pm 4,71 \mathrm{f}$ \\
\hline
\end{tabular}

Keterangan : Angka rata-rata pada tiap kolom yang diikuti huruf yang sama menunjukkan tidak berbeda nyata menurut Uji Jarak Berganda Duncan taraf 5\%. SB = nilai simpangan baku, $\bar{x}=$ ratarata dari ulangan, $\mathrm{Kp}=$ perlakuan $K$. pinnata, $\mathrm{Ai}=$ perlakuan $A$. indica . 
Tabel 2. Rata-rata pakan yang dikonsumsi larva S. litura

\begin{tabular}{rcc}
\hline Perlakuan & Konsumsi pakan $\overline{\boldsymbol{x}} \pm$ SB (g) \\
\hline \multirow{2}{*}{ Kp 50 EC } & Kontrol & $0,037 \pm 0,01 \mathrm{~b}$ \\
& Kp 1\% & $0,040 \pm 0,00 \mathrm{~b}$ \\
& Kp 2\% & $0,038 \pm 0,00 \mathrm{~b}$ \\
& Kp 3\% & $0,034 \pm 0,00 \mathrm{~b}$ \\
Ai 50 EC & Kp 4\% & $0,035 \pm 0,00 \mathrm{~b}$ \\
& Ai 1\% & $0,022 \pm 0,00 \mathrm{a}$ \\
& Ai 2\% & $0,024 \pm 0,00 \mathrm{a}$ \\
& Ai 3\% & $0,021 \pm 0,01 \mathrm{a}$ \\
& Ai 4\% & $0,018 \pm 0,01 \mathrm{a}$ \\
\hline
\end{tabular}

Keterangan : Angka rata-rata pada tiap kolom yang diikuti huruf yang sama menunjukkan tidak berbeda nyata menurut Uji Jarak Berganda Duncan taraf 5\%. SB = nilai simpangan baku, $\bar{x}=$ ratarata dari ulangan $\mathrm{Kp}=$ perlakuan $K$. pinnata , $\mathrm{Ai}=$ perlakuan $A$. indica .

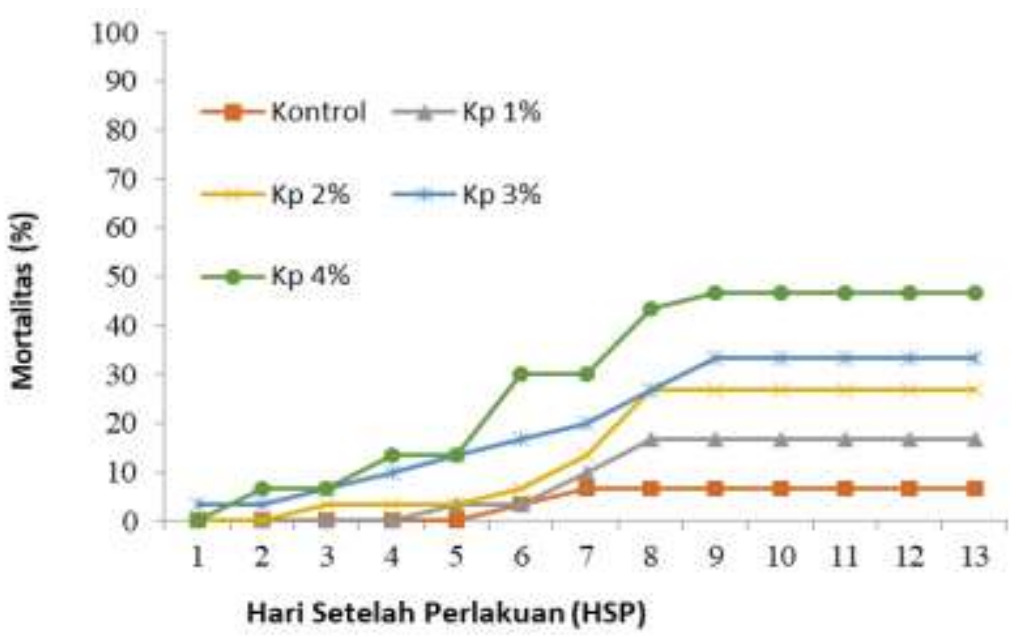

Gambar 1. Mortalitas kumulatif larva S. litura pada perlakuan formulasi cair ekstrak daun K. pinnata 50 EC konsentrasi $1 \%, 2 \%, 3 \%, 4 \%$ dan kontrol.

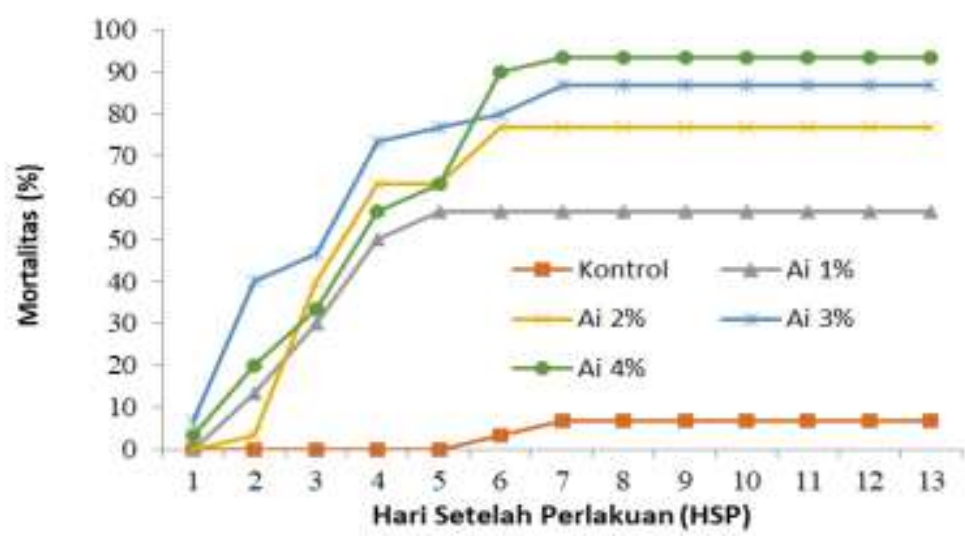

Gambar 2. Mortalitas kumulatif larva S. litura pada perlakuan formulasi cair ekstrak biji A. indica 50 EC konsentrasi $1 \%, 2 \%, 3 \%, 4 \%$ dan kontrol

Hasil penelitian yang dilakukan oleh Melanie dkk (2004) menunjukkan bahwa ekstrak daun cocor bebek (K. daigremontiana) bersifat antifeedant terhadap larva instar IV kumbang koksi (Epilachna vigintioctopunctata Fabricius) (Coleoptera: Coccinellidae) dan tidak bersifat toksik, yaitu tidak menunjukkan gejala keracunan atau paralisis selama 1x24 jam pengamatan, hanya menghambat aktivitas makan pada larva kumbang koksi. Oleh karena itu, pada perlakuan formula ekstrak $K$. pinnata $50 \mathrm{EC}$ perkembangan kematian lebih datar dibandingkan perkembangan kematian pada perlakuan formula ekstrak A. indica $50 \mathrm{EC}$. 
Berbeda halnya saat senyawa insektisida tersebut diuji toksisitasnya terhadap larva B. mori (Lepidoptera) yang mengakibatkan kematian larva uji setelah 24 jam (Supratman, et al. 2000). Hasil pengujian yang beragam tersebut menunjukkan bahwa aktivitas suatu senyawa insektisida juga ditentukan oleh spesies serangga ujinya.

\section{Pengaruh Formulasi Cair Ekstrak $K$. pinnata 50 EC dan A. indica 50 EC terhadap Bobot Larva $S$. litura instar IV}

Bobot larva $S$. litura instar IV pada perlakuan formulasi cair ekstrak daun $K$. pinnata $50 \mathrm{EC}$ tidak berbeda nyata dengan bobot larva dengan kontrol, sedangkan pada perlakuan formulasi cair ekstrak biji A. indica 50 EC menunjukkan bobot larva yang berbeda nyata dengan bobot larva pada perlakuan kontrol (Tabel 3). Data bobot larva tersebut menunjukkan bahwa terdapat kecenderungan semakin tinggi konsentrasi pada kedua jenis perlakuan formula tersebut maka bobot larva uji yang bertahan hidup hingga instar IV semakin rendah. Perlakuan kedua jenis formula tersebut mengakibatkan terhambatnya pertumbuhan serangga uji.

Pengaruh Formulasi Cair Ekstrak $K$. pinnata 50 EC dan A. indica 50 EC terhadap Perkembangan Larva $S$. litura instar I sampai menjadi pupa dan imago

Formulasi cair ekstrak daun $K$. pinnata $50 \mathrm{EC}$ dan ekstrak biji $A$. indica 50 EC mengakibatkan terjadinya penghambatan waktu perkembangan larva mulai dari instar I menjadi larva instar II , III dan IV (Tabel 4). Penghambatan waktu perkembangan pada kedua perlakuan formulasi cair cenderung meningkat seiring dengan kenaikan konsentrasi pada setiap tahap perkembangan. Perlakuan yang menunjukkan penambahan waktu perkembangan terpanjang ditunjukkan pada perlakuan ekstrak $A$. indica pada konsentrasi tertinggi yaitu $4 \%$ dengan penambahan perkembangan yaitu 1,2 hari dari instar I ke II, 5,46 bentuk pupa yang abnormal atau mati, dan pupa yang tidak berhasil menjadi imago. Perlakuan formulasi $K$. pinnata 50 EC juga mengakibatkan gangguan perkembangan larva menjadi pupa dan imago walaupun pengaruhnya tidak sebesar formula ekstrak A. indica 50 EC. Hal tersebut disebabkan perbedaan kandungan jenis senyawa yang terkandung dalam kedua tumbuhan tersebut. Darmawan et al (2013) melaporkan dalam ekstrak metanol $K$. pinnata terdapat senyawa 3',4'-Dimethoxy Quercetin yang merupakan kelompok senyawa flavonoid Hasil penelitian yang telah dilakukan oleh Ghaly et al (2014) ekstrak metanol $K$. beharensis dan $K$. hari dari instar I ke III, dan 4,29 hari dari instar I ke IV, sedangkan pada perlakuan ekstrak $K$. pinnata waktu perkembangan larva terpanjang ditunjukkan pada konsentrasi $4 \%$ dengan penambahan lama perkembangan yaitu sebesar 0,7 hari dari instar I ke II, 2,15 hari dari instar I ke III dan 0,91 hari dari instar I ke IV. Tampak bahwa ekstrak biji A. Indika lebih berpotensi untuk menghambat perkembangan serangga uji dibandingkan ekstrak $K$. pinnata.

Perlakuan formulasi cair ekstrak daun $K$. pinnata $50 \mathrm{EC}$ dan ekstrak biji $A$. indica $50 \mathrm{EC}$ juga mengganggu proses metamorfosa serangga uji $S$. litura. Hal ini ditunjukkan dari persentase keberhasilan larva berkembang menjadi pupa kemudian menjadi imago yang cenderung menurun terutama pada perlakuan formula ekstrak biji $A$. indica 50 EC (Tabel 5.)

Hambatan perkembangan serangga terutama disebabkan gangguan hormonal yang berperan dalam perkembangan diantaranya hormon juvenil, ekdison, dan hormon protorasikotraphik (PPTH) (Chapman, 1998). Selain itu, hambatan perkembangan larva $S$. litura yang memakan pakan berperlakuan disebabkan karena adanya alokasi energi untuk detoksifikasi senyawa toksik. Dalam kondisi makanan tanpa adanya senyawa toksik, energi dari makanan akan digunakan untuk pertumbuhan dan perkembangan. Akan tetapi dengan adanya senyawa toksik pada makanannya maka sebagian dari energi makanan yang seharusnya digunakan untuk pertumbuhan dan perkembangan dialokasikan untuk detoksifikasi senyawa racun (Parkinson \& Ogilvie 2008) sehingga perkembangan larva akan menjadi lebih lama dibanding dengan perkembangan larva tanpa perlakuan ekstrak.

Senyawa azadirachtin yang terkandung dalam ekstrak $A$. indica dilaporkan memiliki aktivitas utama mengganggu kerja hormon serangga sehingga mengakibatkan gagalnya proses metamorfosis serangga (Banerjee \& Rembold, 1992), sehingga menyebabkan larva yang gagal membentuk pupa, longiflora mengakibatkan penghambatan larva menjadi pupa masing-masing $66,6 \%$ dan $86,6 \%$, sedangkan persentase penghambatan pupa menjadi imago masing-masing 86,6\% dan 93,3\%. Lebih lanjut dikemukakan bahwa hasil pemurnian senyawa yang terkandung dalam tumbuhan tersebut merupakan golongan flavonoid yaitu quermecin dari $K$. beharensis dan dua senyawa kamprefol dari $K$. longiflora yang mengakibatkan penghambatan perkembangan larva menjadi pupa masing-masing $63,33 \%, 50 \%$, dan $73,33 \%$, dan penghambatan pupa menjadi imago masing-masing sebesar 70\%, 60\%, dan $76,6 \%$. 
Tabel 3. Bobot larva S. Litura instar IV pada perlakuan formulasi cair ekstrak daun K. Pinnata 50 EC dan ekstrak biji A. Indica $50 \mathrm{EC}$

\begin{tabular}{cccc}
\hline \multirow{2}{*}{ Perlakuan } & Bobot larva (g) \\
$(\overline{\boldsymbol{x}} \pm \mathbf{S B})$ & $\mathbf{N}$ \\
\hline \multirow{2}{*}{ Kp 50 EC } & Kontrol & $0,252 \pm 0,03 \mathrm{~d}$ & 28 \\
& Kp 1\% & $0,251 \pm 0,02 \mathrm{~d}$ & 25 \\
& Kp 2\% & $0,217 \pm 0,02 \mathrm{~cd}$ & 21 \\
Ai 50 EC & Kp 3\% & $0,220 \pm 0,01 \mathrm{~cd}$ & 20 \\
& Kp 4\% & $0,215 \pm 0,04 \mathrm{~cd}$ & 16 \\
& Ai 1\% & $0,156 \pm 0,02 \mathrm{bc}$ & 13 \\
& Ai 2\% & $0,093 \pm 0,07 \mathrm{ab}$ & 7 \\
& Ai 3\% & $0,121 \pm 0,00 \mathrm{ab}$ & 4 \\
\hline
\end{tabular}

Keterangan : Angka rata-rata pada tiap kolom yang diikuti huruf yang sama menunjukkan tidak berbeda nyata menurut Uji Jarak Berganda Duncan taraf 5\%

$\mathrm{SB}=$ nilai simpangan baku, $\bar{x}=$ rata-rata dari ulangan, $\mathrm{Kp}=$ perlakuan $K$. pinnata, $\mathrm{Ai}=$ perlakuan $A$. indica, $\mathrm{N}=$ jumlah larva.

Tabel 4. Lama perkembangan larva S. Litura instar I hingga instar IV setelah diberi perlakuan formulasi cair ekstrak K. Pinnata 50 EC dan A. indica 50 EC

\begin{tabular}{|c|c|c|c|c|}
\hline \multirow{2}{*}{\multicolumn{2}{|c|}{ Perlakuan }} & \multicolumn{3}{|c|}{ Lama perkembangan (hari) $(\mathrm{x} \pm \mathrm{SB})(\mathrm{N})$} \\
\hline & & Instar I - II & Instar I - III & Instar I - IV \\
\hline $\mathrm{A}$ & Kontrol & $3,80 \pm 0,40(30)$ & $6,54 \pm 0,78(28)$ & $9,71 \pm 1,41(28)$ \\
\hline B & $\mathrm{Kp} 1 \%$ & $4,31 \pm 0,51(28)$ & $7,24 \pm 1,29(25)$ & $10,08 \pm 0,83(25)$ \\
\hline $\mathrm{C}$ & $\mathrm{Kp} 2 \%$ & $3,89 \pm 0,50(28)$ & $7,81 \pm 1,10(21)$ & $10,26 \pm 0,88(21)$ \\
\hline $\mathrm{D}$ & $\mathrm{Kp} 3 \%$ & $4,50 \pm 1,12(26)$ & $7,85 \pm 2,57(20)$ & $10,60 \pm 0,92(20)$ \\
\hline $\mathrm{E}$ & $\mathrm{Kp} 4 \%$ & $4,50 \pm 0,84(22)$ & $8,69 \pm 1,21(16)$ & $10,62 \pm 1,17(16)$ \\
\hline $\mathrm{F}$ & Ai $1 \%$ & $4,69 \pm 0,46(13)$ & $7,46 \pm 2,00(13)$ & $12,08 \pm 0,82(13)$ \\
\hline $\mathrm{G}$ & Ai $2 \%$ & $4,43 \pm 0,49(7)$ & $8,71 \pm 1,83(7)$ & $12,14 \pm 0,63(7)$ \\
\hline $\mathrm{H}$ & Ai $3 \%$ & $4,83 \pm 0,37(6)$ & $11,25 \pm 0,43(4)$ & $12,75 \pm 0,43(4)$ \\
\hline I & Ai $4 \%$ & $5,00 \pm 1,00(6)$ & $12,00 \pm 0,00(2)$ & $14,00 \pm 0,00(2)$ \\
\hline
\end{tabular}

Keterangan : SB: simpangan baku; x: rata-rata; KP: K. pinnata; Ai: A. indica; N: jumlah larva.

Tabel 5. Keberhasilan larva S. Litura berkembang menjadi pupa dan imago setelah diberi perlakuan formulasi cari ekstrak K. Pinnata 50 EC dan ekstrak A. indica 50 EC.

\begin{tabular}{|c|c|c|c|c|c|c|}
\hline \multicolumn{3}{|c|}{ Perlakuan } & $\begin{array}{c}\mathrm{N} \\
\text { Larva } \\
\text { (ekor) }\end{array}$ & $\begin{array}{c}\text { Larva menjadi } \\
\text { Pupa } \\
(\%)(x \pm S B)\end{array}$ & $\begin{array}{c}\text { N Pupa } \\
\text { (ekor) }\end{array}$ & $\begin{array}{l}\text { Pupa menjadi } \\
\text { Imago } \\
(\%)(x \pm S B)\end{array}$ \\
\hline $\mathrm{A}$ & & Kontrol & 28 & $92,26 \pm 0,05 \mathrm{c}$ & 26 & $76,85 \pm 0,01 b$ \\
\hline B & & $\mathrm{Kp} 1 \%$ & 25 & $76,39 \pm 0,09 \mathrm{bc}$ & 19 & $57,94 \pm 0,07 \mathrm{~b}$ \\
\hline $\mathrm{C}$ & Kp 50 EC & $\mathrm{Kp} 2 \%$ & 21 & $74,17 \pm 0,11 \mathrm{bc}$ & 16 & $74,60 \pm 0,18 b$ \\
\hline $\mathrm{D}$ & & $\mathrm{Kp} 3 \%$ & 20 & $60,32 \pm 0,12 a b c$ & 12 & $49,44 \pm 0,18 b$ \\
\hline $\mathrm{E}$ & & $\mathrm{Kp} 4 \%$ & 16 & $64,05 \pm 0,08 a b c$ & 10 & $61,11 \pm 0,28 b$ \\
\hline $\mathrm{F}$ & & Ai $1 \%$ & 13 & $62,22 \pm 0,03 \mathrm{abc}$ & 8 & $72,22 \pm 0,21 b$ \\
\hline G & Ai $50 \mathrm{EC}$ & Ai $2 \%$ & 7 & $36,11 \pm 0,31 \mathrm{ab}$ & 4 & $55,56 \pm 0,42 b$ \\
\hline $\mathrm{H}$ & & Ai $3 \%$ & 4 & $16,67 \pm 0,24 \mathrm{a}$ & 1 & $0,00 \pm 0,00 \quad a$ \\
\hline I & & $\mathrm{Ai} 4 \%$ & 2 & $33,33 \pm 0,47 \mathrm{ab}$ & 1 & $0,00 \pm 0,00 \quad a$ \\
\hline
\end{tabular}

Keterangan : Angka rata-rata pada kolom yang diikuti huruf yang sama menunjukkan tidak berbeda nyata menurut Uji Jarak Berganda Duncan pada taraf $5 \%$.

$\mathrm{SB}$ : simpangan baku, $\mathrm{x}$ : rata-rata, Kp: K. Pinnata, Ai : A. Indica, $\mathrm{N}$ : jumlah serangga

\section{KESIMPULAN}

Formulasi cair ekstrak biji A. indica $50 \mathrm{EC}$ lebih toksik dibandingkan dengan formulasi cair ekstrak $K$. pinnata 50 EC terhadap larva larva $S$. litura. Selain itu, formulasi cair ekstrak biji A. indica 50 EC mengakibatkan penurunan bobot larva dan konsumsi pakan, memperpanjang waktu perkembangan larva, dan menurunkan tingkat keberhasilan larva berkembang menjadi pupa dan imago.

\section{DAFTAR PUSTAKA}

Banerjee S, and Rembold H, 1992. Azadirachtin a interferes with control of serotonin pools in the Neuroendocrine System of Locusts [J]. Naturwissenschaften, 79: 81-84. 
Chapman RF. 1998. The Insect, Structure and Function, $4^{\text {th }}$ ed. Massachusetts: Cambridge University Press.

Darmawan A., Megawati., Fajriah S. 2013. 3',4'Dimethoxy Quercetin, a Flavonol Compound Isolated from Kalanchoe pinnata. Journal of Applied Pharmaceutical Science 3(1): 88-90

Hutapea, J.P. 1994. Inventaris Tanaman Obat Indonesia. Badan ' Penelitian dan Pengembangan Kesehatan. Departemen Kesehatan. Jakarta. Indonesia. 3: Hal 117-118.

Ghaly, N. S., Mina, S.A., Aziz, N.F.A, and Sammour E.A. 2014. Insecticidal activity of the main flavonoids from the leaves of Kalanchoe beharensis and Kalanchoe longiflora. Journal of Natural Products, 7: 196-202.

Gruber, L.C. and Karganilla, G.S. 1989. Neem Production and use. Philippine-German Biological Plant Protection Project Bureau of Plant Industry Department of Agriculture 692 San Andress Street Malate. Philippiness.

Kalshoven L.G.E. 1981. The Pests of Crops in Indonesia. van der Laan PA (Rev. \& trans.) Rotschild GHL (Asssist.) PT Ichtiar Baru van Hoeve, Jakarta.

Marwoto dan Suharsono. 2008. Strategi dan Komponen Teknologi Pengendalian Ulat Grayak (Spodoptera litura Fabricius) pada Tanaman Kedelai. Balai Penelitian Tanaman Kacang-kacangan dan Umbi-umbian, Malang.

Mayanti, T., Huspa, D. H. P., Nurlelasari, Safari, A., dan Supratman, U. 2011. Senyawa Bufadienolida yang bersifat Insektisida, Daigremontianin dari daun Cocor Bebek (Kalanchoe daigremontiana). Valensi 2(2): 379-383.

Melanie., Hermawan W., dan Supratman, U. 2004. Bioaktivitas Ekstrak Daun Sosor Bebek (Kalanchoe daigremontiana Hammet \& Perrier) Terhadap Larva Kumbang Koksi (Epilachna vigintioctopunctata Fabricius). Jurnal Biotika 3(2): 49-55.

Melanie., Kasmara H., dan Ambarwaty, S.C. 2006. Pengaruh Ekstrak Daun Cocor Bebek (Kalanchoe daigremontiana Hammet \&
Perrier) Terhadap Perkembangan Dan Lolos Hidup Kumbang Koksi Herbivora (Epilachna vigintioctopunctataFabricius). Jurnal Biotika 5 (1): 17-24.

Metcalf, R. L. and Luckman, W. H. 1982. Intruduction to Pest Management. Wiley Intersci Publish Moustiuer John of Metz Wiley and Sons, New York.

Mordue (Luntz), A.J., Simmonds, M.S.J., Ley, S.V., Blaney, W.M., Mordue, W., Nasiruddin, M., and Nisbet, A.J.. 1998. Actions of azadirachtin, a plant allelochemical, against insects. Pestic. Sci. 54: 277-284.

Rembold, H. 1988. Isomeric Azadirachtin and Their Modes of Action. In M. Jacobson (ed). Focus on Phytochemical Pesticides. Vol. I : The Neem Tree. CRC, Boca Raton, Florida. pp. 4767.

Steel R.G.D., Torrie J.H.. 1993. Prinsip dan Prosedur Statistik: Suatu pendekatan biometrik, penerjemah; Sumantri B, editor. Jakarta: PT. Gramedia Pustaka Utama.

Sudarmadji, D. 1993. Prospek dan Kendala dalam Pemanfaatan Mimba sebagai Insektisida Nabati. Prosiding Seminar Hasil Penelitian Dalam Rangka Pemanfaatan Pestisida Nabati. Balai Penelitian Tanaman Rempah dan Obat. Bogor. Hal. 223-224.

Supratman, U., Fujita, T., Akiyama, K., and Hayashi, H. 2000. New Insecticidal Bufadienolide, Bryophyllin C, from Kalanchoe pinnata. Biosci. Biotechnol. Biochem., 64 (6), 13101312.

Parkinson A, Ogilvie BW, 2008. Biotransformation of xenobiotics. Di dalam : Klaassen CD, editor. Casarett and Doulls" Toxicology. The Basic science of Poisons. New York. Mc Graw Hill. 161-304 pp

Wowiling, J. 2010. Pestisida Nabati Mimba (Azadirachta indica A. Juss) Dalam Pengendalian Organisme Pengganggu Tumbuhan OPT. Seminar Regional Inovasi Teknologi Pertanian, mendukung Program Pembangunan Pertanian Propinsi Sulawesi Utara.

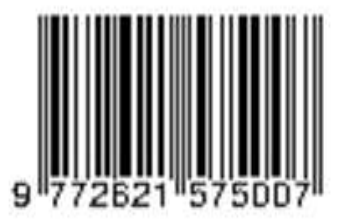

